\title{
Student Wellbeing in the Teaching and Learning Environment: A Study Exploring Student and Staff Perspectives
}

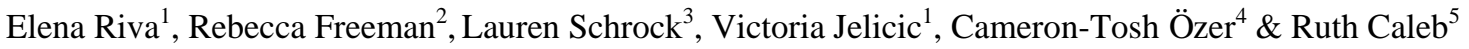 \\ ${ }^{1}$ Institute for Advanced Teaching and Learning, University of Warwick, Coventry, United Kingdom \\ ${ }^{2}$ School of Life Science, University of Warwick, Coventry, United Kingdom \\ ${ }^{3}$ Warwick Manufacturing Group, University of Warwick, Coventry, United Kingdom \\ ${ }^{4}$ Warwick Medical School, University of Warwick, Coventry, United Kingdom \\ ${ }^{5}$ Metanoia Institute, London, United Kingdom \\ Correspondence: Dr Elena Riva, Director of Studies, Institute for Advanced Teaching and Learning, Coventry, \\ University of Warwick, United Kingdom. E-mail: e.riva@warwick.ac.uk
}

Received: October 7, 2020

doi:10.5539/hes.v10n4p103
Accepted: October 29, $2020 \quad$ Online Published: November 16, 2020

URL: https://doi.org/10.5539/hes.v10n4p103

\begin{abstract}
Internationally and in the UK universities are facing a crisis of student wellbeing. In this context, it is important to research the impact of the teaching and learning environment and experiences, including the relationships between students and staff, on student wellbeing. While separate pieces of research on students' wellbeing have addressed student and teacher perspectives on the role of learning experiences, we identified an opportunity to address the perspectives of both students and staff, including non-academics, in the same study. This study advances work on student wellbeing, recognising an interdependency between staff and student wellbeing. It adds to current research in identifying student-centred learning and assessment, intercultural awareness, international integration, and emotional intelligence as enablers of positive student wellbeing. The findings of this research also demonstrate the crucial role of the teacher-student relationship in impacting students' (and staff) wellbeing and suggest solutions and areas for development that reflect the complexity of the Higher Education environment in which they are located.
\end{abstract}

Keywords: student wellbeing, student experience, teaching and learning, compassion, staff wellbeing

\section{Introduction}

In the United Kingdom (UK) and internationally universities are facing a crisis of student wellbeing (Macaskill, 2012, Mikalajūnaite, 2019). In the UK, a study by the Institute for Public Policy Research found that students disclosing a mental illness has increased nearly five times since 2006 (Thorley, 2017). A 2015 survey by the National Union of Students found $78 \%$ of student respondents had experienced mental health issues in the previous year, and a third of respondents said that they had suicidal thoughts (Gil, 2015). A recent joint study by AdvanceHE and the Higher Education Policy Institute found that student wellbeing is less than that of the general population, and continues to decline (Neves \& Hillman, 2018). This, coupled with pressures from the Office for Students for institutions to effectively respond to this growing issue (University UK, 2015; University UK, 2018), has ensured that universities make student wellbeing a priority (Barden \& Caleb, 2019). Many studies have argued the importance of considering wellbeing as it affects the whole students population (Houghton and Anderson, 2017; Marshall, 2019), reinforcing the need for an urgent action within the sector. Stressors such as academic workload, high level expectancy of academic performance (Kadison \& DiGeronimo, 2004; Levecque, Anseel, De Beuckelaer, Van der Heyden \& Gisle, 2017) and financial burden (Denovan \& Macaskill, 2017) combined with changes in lifestyle (Kruisselbrink Flatt, 2013; Deasy, Coughlan, Pironom, Jourdan \& Mannix-Mcnamara, 2014; Wonkhe, 2019) are some of the reasons for the current situation (Pidgeon, Rowe, Stapleton, Magyar \& Lo, 2014).

Students' overall experience in Higher Education is highly impacted by the teaching environment and learning experiences (Barden \& Caleb, 2019). They play a key role in effective students' learning, but also in their personal wellbeing and ability to flourish and become engaged citizens (Hammond, 2004; Okanagan Charter, 2015). While there are distinct calls for addressing student wellbeing in teaching and learning, this remains an 
under-researched topic (Stanton, Zandvliet, Dhaliwal \& Black, 2016). Studies have suggested improving student support for mental health, such as counselling or wellbeing skills training (Conley, Durlak \& Kirsch, 2015), embedding wellbeing into the curriculum (Houghton \& Anderson, 2017), and developing wellbeing positive teaching techniques (UBC Wellbeing, 2016). These are very helpful suggestions for implementing wellbeing support within the teaching and learning environment, but it is important to recognise the whole, multi-faced, complex institutional context for interventions to be successful.

We therefore identified the relevance of using an approach to studying student wellbeing which takes into account the experiences of both students and staff as a means to appreciate the uniqueness of the university context and the diversity of the stakeholders in order to inform context led strategies for wellbeing (Universities UK, 2019). Whilst there are calls to take a comprehensive approach to wellbeing, whether as a university via the so called "whole university approach" (Seldon \& Martin, 2017; Baik et al., 2016) or as a national programme of health (Dooris \& Doherty, 2010), there are few examples of research that take account of both student and staff experience in the same study. Studies on student wellbeing tend to rely on perspectives exclusively from students (Stanton et al., 2016; Baik, Larcombe \& Brooker, 2019) or teachers (Hughes, Panjwani, Tulcidas \& Byrom, 2018). We argue that it is important to include students and teachers voices in the same study for two reasons. First, wellbeing, teaching, and learning are relational activities. Second, when looking at student wellbeing in teaching and learning we must also take into consideration professional staff members such as librarians, career advisors, and wellbeing services staff who support student learning. Therefore the inclusion in the study of students, of different years of study and disciplines, and staff, of both academic and non-academic roles, provided an opportunity to consider the voices of the wider university community, while addressing a deficit in including non-academic staff in Higher Education research in an area where they have significant experience and influence (Graham, 2010). As result, our research findings captured staff and students' intertwined experiences within the teaching and learning environment, giving a voice to the whole university community.

\section{Student Wellbeing and the Teaching and Learning Environment}

There are many arguments for developing universities as environments that sustain and enhance student wellbeing. Student wellbeing is integral to learning (Bücker, Nuraydin, Simonsmeier, Schneider \& Luhmann, 2018). Poor student wellbeing can impact academic achievement (Ansari \& Stock, 2010; Geertshuis, 2019), and a lack of resilience to protect wellbeing can limit a student's learning capacity and engagement with consequences for continuation and attainment (Turner, Holdsworth \& Scott-Young, 2017; McIntosh \& Shaw, 2017).

On a more philosophical level, higher education is about the development of "a whole, integrated person", (Keeling, 2014: 144), preparing students to deal with an unknown future as argued by Barnett (2012:65). While some of these ambitions may be undermined by the marketization of Higher Education (McCulloch, 2009), good teaching and learning is a process of "becoming" and development of the individual agency, necessary for longer-term wellbeing (Sabri, 2011).

The construction of the concept of wellbeing within the university teaching and learning environment has been undertaken in several studies. It is useful here to make the distinction between mental wellbeing and mental health. Many individuals have a good sense of wellbeing while living with a mental illness, while others have a poor sense of wellbeing with no mental illness diagnosed. Stanton, et al. (2016) proposed a definition of wellbeing drawn from their student participants that includes "social, physical and mental dimensions" that require "balance" in order to achieve a "sense of happiness and fulfilment" (p. 92). Such a conceptualisation of wellbeing links with a positive psychology, in which wellbeing is recognised in two forms: hedonic (feelings of pleasure) and eudaemonic (self-actualisation) (Deci \& Ryan, 2008). From a pedagogical perspective, these two forms of wellbeing are reinforcing: positive feelings support learning, and learning enables the becoming of one's full human self (Harward, 2016). This is not to say that the aim is for students to feel happy all the time within the learning process but that wellbeing provides the basis for successful, and at times challenging, learning to take place.

As part of our focus groups, students and staff reflected on their own perceptions of wellbeing based on their personal experiences within learning settings. Student wellbeing is subjective and the qualitative method ensured that we were able to recognise individual voices amongst the collective to understand in depth of the experiences of students and staff and their interrelatedness.

This research adopts a broad definition to teaching and learning environments and experiences, including those beyond the classroom to consider student wellbeing as a whole community challenge. 


\section{Methods}

The study took place in 2019 in a large, Russell-Group university in England. Students and staff were invited to participate via university mass emailing. Focus groups were coordinated and facilitated by four members of the research project team (three females and one male), all of whom had conducted qualitative research as part of their Master and/or PhD qualification and/or Academic career. The researchers were allocated to facilitate focus groups that contained participants with whom had no prior relationship. In order to ensure consistency, two guides (Appendix A) were devised and utilised to facilitate each focus group: one for the students and the one for the staff focus groups. All the facilitators were trained and a pilot of both the staff and students' focus groups occurred in presence of all facilitators (data of the pilot were not included in the research study). A trained observer was allocated to each focus group to take notes and annotate silent consent to statement (e.g. nodding). The student focus groups focused on the students' understanding and experiences of wellbeing in teaching and learning environments and experiences. The staff groups (academic, professional and service roles) focused on the same criteria but with more emphasis on the support systems available through academic and professional services. After obtaining ethical approval, all focus groups where carried out in line with the university ethical recommendations and participants were informed about the scope of the focus group before starting.

\subsection{Sample}

In total, 13 focus groups took place in Spring 2019 at the university. Each focus group was constituted of a minimum of five participants and a maximum of ten. Five were staff-only focus groups and eight were student-only (three PG and five UG). The postgraduate student focus groups included students from postgraduate taught and postgraduate research degrees. A range of staff members took part in the focus groups, including professors, academic supervisors, tutors, librarians, skills advisors, administrators, and other interested parties who directly or indirectly support student wellbeing and/or teaching and learning. In total, of the 340 university members who signed up, 120 participated in the focus groups out of the 135 invited. Reasons for non-participation was mostly associated to self-declared illness on the day of the scheduled focus group. Among the university's members who signed up for the focus group, we ensured to invite, for both staff and students focus groups, similar numbers of participants from all the three faculties in recognition of the fact that the teaching and learning environment can differ depending on disciplinary settings. We also actively ensured the presence of a variety of voices, prioritising the invitation of students and staff from different ethnic backgrounds and nationalities in order to capture the diverse range of experiences within the learning environment. We utilised the same principles when allocating students and staff to the different focus groups, making sure as much as possible that participants belonged to different disciplinary and ethnic or international backgrounds. Again, we actively offered spaces to non-academic staff, ensuring the presence of at least two people from this section of the university in each staff focus group. While the size of the sample is small in relation to the university population as a whole, the participants represented a broad cross-section of the university (Table 1).

Table 1. Participants Information

\begin{tabular}{lllll}
\hline Characteristics/Our participants & UG & PG & Staff & Total Sample \\
\hline Number of participants & 47 & 27 & 46 & 120 \\
BAME & 17 & 13 & 11 & 41 \\
International & 21 & 14 & 16 & 51 \\
Age range & $18-30$ & $22-40$ & $26-90$ & $18-90$ \\
Gender & 36 female, 10 male, & 19 female, & 33 female, & $73 \%$ female, 26\% male, \\
& 1 "other"a & 8 male & 13 male & $1 \%$ "other"a \\
\hline
\end{tabular}

Note: ${ }^{a}$ Identified themselves as "other"

In order to avoid perceptions of power influencing the dynamics of the conversations the students and staff focus groups were held separately rather than as collaborative events. For the same reason, junior researchers facilitated students' focus groups while the more experienced enabled the staff focus groups.

\subsection{Analytical Approach}

Each focus group was recorded and transcribed. Transcription were not returned to participants before analysis but a draft of the final report was shared with them for gathering their comments and feedback before publication. The thematic analysis was executed following a recognised six-phased method (Nowell, Norris, White \& Moules, 2017; Braun \& Clarke, 2006) and the themes were derived from the data. The data were coded separately by four researchers utilising Excel. All members of the research team worked systematically through the entire data set, 
giving full and equal attention to each data item. Individual extracts were coded as many times as considered relevant and weekly, minute recorded research meetings were held during the coding process to facilitate peer-briefing and cross-checking and to ensure consistency in coding. Using template analysis (King, 2004) and through an iterative process of comparison and classification repeated until all researchers were satisfied (Nowell et alt., 2017), the codes were grouped into four themes. We also utilised diagramming for visualising connections between themes and looking for further "themes" interactions. Each theme included between two and four sub-themes. For example, consider the following excerpt from a student response (italicized text indicates the coded elements of the response):

"If the environment is really open-minded, we are able to give our own opinions and we are more likely to talk about our ideas and feel good about it" (PGT Student)

All three italicized considerations fall within the theme "student-centred learning and assessment". The first observation speak to the sub-theme of "openness" and the other two to the sub-theme "active engagement". The four major themes and sub-themes are outlined in Table 2.

Table 2. Themes and Subthemes

\begin{tabular}{ll}
\hline Themes & Subthemes \\
\hline Student-Centred Learning and Assessment & Personalisation, Flexibility, Openness, Active Engagement \\
Lack of Intercultural and International Integration & $\begin{array}{l}\text { Limited sense of belonging, Lack of group } \\
\text { diversity, Lack of fostering of cultural awareness }\end{array}$ \\
Emotional Intelligence & $\begin{array}{l}\text { Approachability, Effective communication, } \\
\text { Capacity of listening, Care }\end{array}$ \\
Staff wellbeing & Negative staff wellbeing, "Staff/student wellbeing loop" \\
\hline
\end{tabular}

\section{Results}

Following the sharing of different perspectives around the concepts of wellbeing and teaching and learning environment, students and staff were invited to recall and reflect upon positive and negative feelings and experiences happened to them in such environments and during learning experiences. Four key themes were constructed from the data analysis: (1) student-centred learning and assessment, (2) lack of intercultural and international integration, (3) emotional intelligence and (4) staff wellbeing are crucial enablers or barriers to wellbeing positive experiences in the learning environment and process. Evidence is presented from the focus groups to illustrate these themes.

\subsection{Student-centred Learning and Assessment}

The analysis of the data shows that student-centred learning and assessment, from classroom setting to assignments' details, is an enabler of student wellbeing. If involved in this type of learning, fostered by teachers, students feel more valued, engaged, and noticed, which has a positive effect on their wellbeing.

Good teaching practice, including learning student names, "checking- in" on students before, during, and after class to assess learning, and showing an interest in student's lives and learning create the personalised, student-mindful experience necessary to support students' wellbeing:

"It was really nice that [the teacher] remembered our names! There were a lot of people that class ( 50 people) but it was really nice to be recognised as an individual rather than just "as student"'”. (UG Student)

"It is really demotivating when they're [teachers] not really interested in you individually or the group really. It's nicer when people know their stuff, they're passionate for their stuff, but they also kind of take the time to check-in" (PGT Student)

In the same way, a student-focussed assessment strategy where students perceive that their personal, future aspiration, and/or their best interests are taken into account in the assessments' design helps to reduce existing stressors.

"I need to do assessments and write a dissertation if I want to graduate, I think they can be more tailored, like the professor or the University can arrange some internship, and assessments connected to the real world, because I want to figure out what kind of job I can do as a student studying my major not just produce something for them. I'm confused about my career and it's stressing me out." (PGT student)

Openness, flexibility, active engagement, identified as elements fostered by staff that positively impact on student wellbeing, are all main ingredients of student-centred learning experiences, from lecture's delivery to 
assessment's types and deadlines.

"I've had lectures where the lecturer will literally just lecture, and then I've had others where there will be audience participation, and I've noticed that I've felt better in those ones just because we've been encouraged to ask and to actually engage" (UG Student)

"If the environment is really open-minded, we are able to give our own opinions and we are more likely to talk about our ideas and feel good about it" (PGT Student)

"When there are a lot of assessment deadlines, you have a lot of stress and a lot of pressure and then there are times when there aren't deadlines. It does not make sense." (UG Student)

"If you have a teaching and learning environment which is, say, massively over-assessing students, which I think is something that we do here, that can have an impact on student wellbeing [...] and things like unnecessary over-assessing, or over-assessing in very specific ways that aren't necessarily particularly innovative and flexible can have a detrimental impact on it." (Academic Staff member)

Yet, learning experiences that appear as student-centred can also negatively impact on wellbeing. We argue that this happens if such activities are not adequately planned and delivered. In achieving openness, activeness and engagement, it is important to balance with not forcing engagement and to provide clear, flexible support and feedback.

"Sometimes I feel a bit pressured in seminars to say something and I get myself in a flurry because the seminar tutor goes round in a circle and everyone has to say something, because they want us active, and that's what I don't like. It is not good for how I feel. Because if I have something to say, I'll say it, but if I don't, I'll just talk some utter rubbish" (UG Student)

"You literally get dropped into a pond of, okay, write an essay, this is your topic, go free, be creative, it's all about you. But you don't know what they [lecturers] expect of you, they do not have the time to talk to you, and you don't know how much effort you should put into it, and it's just like a big overwhelming juggling...it doesn't make any sense so, less freedom, more help..." (PGT Student)

\subsection{Lack of Intercultural and International Integration}

Intercultural and international integration is often lacking within learning experiences and our analysis has recognised this as a major obstacle to students' wellbeing. The negative wellbeing experiences are associated to inabilities of developing a sense of belonging to the whole class and to a lack of teacher-supported group diversity that obstacles students to reach their personal goals. These factors generate anxiety and suboptimal wellbeing experiences.

"I want to speak English and I am here for improving my English but in my work group there are all the Chinese people, so we use Chinese. I sit there and I think I waste my time and I feel bad. I think the professor - if the professor can locate the people randomly, it will be more...good" (PGT Student)

Integration needs to be fostered and facilitated by an attentive staff within the context of a more widely raised university cultural awareness. In fact, misunderstandings and stigmas within non-supported culturally diverse groups generate feelings of rejections in some and anxiety in others.

"You can understand how someone might have these frustrations, that if it's really difficult for me to understand what this person is saying, it's going to be really hard for me to work with them, and that worries me because that will have an impact on my academic success. Whereas, from the international student's perspective, you can see how that's quite a horrendous experience to go through, a constant rejection. And we've seen ... that kind of example endlessly with group work, in a myriad of academic contexts." (Academic Staff Member)

"Trying to really facilitate and embed cultural awareness, I think is something that's really important. Obviously that's not just the role of a kind of a teacher, because I think that's an institutional issue as well, including us in the academic services." (Non-academic Staff Member)

\subsection{Emotional Intelligence}

Human qualities and behaviours (to include care, kindness and compassion) play an important role in enhancing the wellbeing of students within the teaching and learning environment. There is a need for the display of these qualities in university staff members that are directly involved in the students' academic journey, such as tutors, lecturers, library staff and career advisors.

"When people are very energetic and they show the love for what they're doing... it's important, no matter how deep they went to whatever they're studying, to be able to answer very basic questions and not be like, "Okay, 
that's a very basic question - go and find it yourself". You have to be approachable as well."(PGT Student)

Staff members, both academics and non-academics, further articulated the core need to possess emotional intelligence in their interaction with students. Directing care by employing soft skills, such as approachability, empathy, and showing a capacity for listening and communicating effectively results in reducing the stressors that individuals experience in the teaching and learning environment.

"If you aren't showing the compassion and caring, if a student presents a problem when you have your kind of feedback and support hours but you don't actively support them, or you don't put them in touch with other services that can support them, then that's going to knock somebody's confidence" (Academic Staff Member)

"I expect the teaching and learning environment to be inclusive and humane and to feel cared for, whether I'm a student or a member of staff, and that requires a degree of humility as well." (Non- academic Staff member)

Importantly, it is noted that there is a necessity for these attributes of kindness and care to be displayed in all the relationships adopted with others within the learning process.

"If someone, I am talking about both students and teachers, is unkind to another repeatedly, that can affect their mental health in a negative way." (UG student)

"So, it's [wellbeing] definitely how you treat people and other students because that impacts, how you feel about yourself and how comfortable you feel in opening up in a lecture I think, and also how the departments treat you and how they communicate to you." (PGT student)

When the emotional intelligence is minimal, then this acts as a barrier to students trying to improve their wellbeing.

"Sometimes, you may find yourself wanting to...discuss something, but you feel the fear to be judged by the person you're going to - say, personal tutor" (PGT Student)

Yet, while emotional intelligence is significant for student wellbeing, it is not necessarily developed or valued across the university:

"Although compassion is really important, this is not the message that most of the people in universities have received." (Non Academic Staff Member)

\subsection{Staff Wellbeing}

From our analysis, it was deduced how staff wellbeing influences student wellbeing. On one hand, staff discussed the way in which the institutional environment effects their own wellbeing and on the other, they also identified how their personal feelings and experiences play a key role in the classroom. We understand this to be a sort of "student/staff wellbeing loop" in that staff wellbeing was profoundly interlinked to students' wellbeing within the teaching and learning setting and this can be challenging in the context of wider pressures on staff performance.

"I think...if we're fed up because we're not feeling cared about by our department, by colleagues, by the institution, it does go into the classroom with us, or a lecture theatre, and I don't...I don't have a sense that that is well understood here." (Academic Staff Member)

Struggles associated with excessive workload and working in a stressful environment prevent staff from being able to effectively embed best practices and to discharge their responsibility towards students' welfare and pastoral needs, ultimately impacting on students' wellbeing.

"I think a more holistic approach to wellbeing is needed because stressed, overworked staff cannot relate to, engage with or support students in the classroom, and beyond. They haven't got the time, they haven't got the patience, they haven't got the will because they're desperately trying to meet their next target." (Non-academic Staff Member)

\section{Discussion and Conclusions}

The overall aim of this study was to understand the potential impact of the teaching and learning environment and experiences on students' wellbeing and to draw on our findings for giving useful suggestions to universities, researchers and policy makers to address this timely issue. Our approach embedded participation of students and staff in order to recognise student wellbeing within the contextual dynamics of the relationships between student and student, students and staff, and between staff. The themes that were constructed from the data analysis highlight the relevant role played by the educational environment and experiences, and allowed us to recognise the positive impact granted by a 1) student-centred, 2) integrated, inclusive and 3) caring learning setting. In addition, we identified 4) staff wellbeing as key factor, highlighting the interdependency between staff and 
students' wellbeing in Higher Education.

\subsection{The Teacher- student Relationship}

Looking at the four themes with the aim of offering recommendations, it is essential to note that the teachers-student relationship (TSR; "teacher" is a key figure in the learning environment, academic or non-academic staff), plays a key role across the different areas for creating learning experiences conducive to positive students' wellbeing.

A first suggestion for institutions would be to look more actively at TSR when searching for solutions to the student wellbeing crisis and in the context of embedding wellbeing in the curriculum (Houghton \& Anderson, 2017). In fact, the significance of the interpersonal relationship between students and teachers within kindergarten and schools is widely understood (Bernstein-Yamashiro \& Noam, 2013; Roorda, Koomen, Spilt \& Oort, 2011) as well as its impact on students' wellbeing (Graham, Powell \& Truscott, 2016; Wyn, Cahill, Holdsworth, Rowling \& Carson, 2000), but it is under-researched in Higher Education (Hagenauer \& Volet, 2014). This study suggests that, as well as affecting students' successful study progress, course satisfaction, retention and achievement (Pascarella \& Terenzini, 2005), TSR also impacts on the students' wellbeing in universities' teaching and learning environment. This reinforces the observation of O'Keefee (2013) who explored the ways that positive student/staff relationships can enhance students' sense of belonging, often associated to wellbeing. Other characteristics of positive TSR such as openness, respect, support, connectedness and engagement (Jackiln \& Le Riche, 2009; Fitzmaurice, 2008) are indicated as main drivers in creating wellbeing conducive learning experiences in our own research. When such TSR characteristics are displayed, inclusive and active student-centred learning and assessment experiences are enabled, where students are looked at as the "whole person" rather than as an indistinguishable part of the student body (Morgan \& Houghton, 2011). Students can effectively connect to staff and students alike and engage more actively with their learning. In student- focussed settings, stressors which affect students' wellbeing are alleviated. On the other hand, a less positive TSR characterised by minimal engagement and relatedness can contribute to an environment where a lack of integration is observed among students, in particular from an international background. This leads to moments of isolation and discomfort and ferments complex issues of cultural misunderstanding and stigma (Royal College of Psychiatrists, 2011; Young Minds, 2006), reinforcing barriers to connecting among students and ultimately impacting on the students' learning experience and wellbeing. In this context, staff can play a central role in providing opportunities for students to develop peer relationships and to engage in meaningful interactions beyond existing cultural barriers, as also championed by Meehan (2019). Consistently with previous research (Baik et al., 2019), it is revealed the positive wellbeing impact of emotional intelligence, suggesting once more that traits often associated to "good TSR" such as care (Komarraju, Musulkin \& Bhattacharya, 2010) and approachability (Denzine \& Pulos, 2000) have a favourable impact on students as enabling them to feel "valued as people". This observation is particularly relevant when looking at the difficult situation due to Covid-19 pandemic in which in a very real sense, students are unable to be present in the physical learning environment and will face inequalities in their ability to access support. The role of teachers, tutors and welfare services in being aware of student wellbeing and demonstrating care is ever more important at this difficult time.

Whilst acknowledging the role played by TSR in creating a wellbeing positive teaching and learning environment for students, it is essential to pay attention to the other "actors" involved in this relationship: the teachers. As identified in a number of recent studies, academic and non-academic staff wellbeing and mental health is worryingly deteriorating across the Higher Education sector (Morrish, 2019; O'Brien \& Guiney, 2018). The necessity of identifying solutions for concerns linked to increased pressure to perform within the context of limited time (Ball, 2003), excessive workloads, precarious contracts, a culture of workplace surveillance and often a lack of staff wellbeing support (Gulliver, Farrer, Bennett \& Griffiths, 2019) was identified in our research. In this study we demonstrated that wellbeing for staff and students are linked in what we defined as "student/staff wellbeing loop". Staff precarious welfare restricts their ability to positively impact student wellbeing as it prevents them from effectively contributing to a caring, kind, and compassionate learning environment. This is similar to what has been observed in primary school settings (Roffey, 2012) and resonates with the findings of a healthcare study that explored the links between patients' experiences of health care and nurses' experiences of work, demonstrating a strong connection between staff happiness and patient satisfaction (Maben, 2012 and 2013). Student and staff wellbeing in teaching and learning settings are two sides of the same coin, needing the same "protection" and acknowledgement as priorities within Higher Education. In other words, supporting staff wellbeing is an essential action for adequately sustaining students' welfare. 


\subsection{Creating Compassionate Universities}

When translating our findings into further recommendations for universities, researchers and policy makers, we can be guided by our staff and students. They recognised a need for "genuineness", "connection", "care" and "compassion" for one-another as the fabric of the interpersonal relationships needed for education (TSR as well as peer-peer and staff-staff relationships) that takes account of both student and staff wellbeing. Development of a compassionate environment needs to be extended within institutions with access for all members of the community (Morrish, 2019). In this context, compassion is attentiveness for another's needs, and a readiness to alleviate the suffering of others in order to enhance their wellbeing (Worline \& Dutton, 2017). Embedding care and compassion in organizational structures leads to connectedness, resilience and wellbeing (Atkins \& Parker, 2012) as well as improved performance and productivity of the organization's members (Lilius et al., 2008 and 2011). Promoting care and compassion might feel conflicting with the values of profit-driven organizations (Thompson, 2007), but numerous "compassionate" initiatives and structures are widely described within the organizational scholarship (Madden et al., 2012, Bartunek \& Rynes, 2010).

Universities are, or should be, "caregiving organisations" (Kahn, 2005), because of their primary scope of supporting students in their learning and development as well as their wider contribution to local communities and society. However, some of this is at odds with the neoliberal instrumentalisation and commodification of Higher Education which Smyth, (2017) and Waddington (2016 and 2017) argue has created "compassion gaps". Our participants also noted how universities do not display an interest in valuing nor developing compassion across the institution. We argue that, while not being in loco parentis, universities have a duty of care towards students and staff (House of Commons, 2019) and "whole organization" structures for effectively promoting and preserving compassionate practices at every level (Lilius, Worline, Dutton, Kanov \& Maitlis, 2011, Lilius et alt., 2008) are crucial for ensuring inclusion and support for the whole community. Specific ways for closing the "compassion gap" in Higher Education institutions have been identified (Waddington, 2017) as, for example, promoting a variety of practices of kindness at individual, group and organizational level, starting from the academic leadership (Waddington, 2018). We believe that the creation of such environment also relies on the provision of targeted wellbeing interventions aimed at supporting staff wellbeing (e.g. available wellbeing services, adequate staff development programmes, revision of current workload models, etc.). In addition, promoting this cross-institutional embedding of compassion and care complements, supports and reinforces the widely recognised "whole university approach" to wellbeing championed in the University Mental Health Chart as a "multi-stranded approach which recognises that all aspects of university life can support and promote mental health and wellbeing" (Hughes \& Spanner, 2019, p.10).

This study has remarked the crucial impact of the learning environment and experiences on students' wellbeing and the strategic necessity of looking at the relationship between teachers and students within this context. TSR remains an under-researched field and is an area that should underpin new wellbeing research in Higher Education. If universities want to positively contribute to students' wellbeing in learning environments, it is urgent also to sustain staff wellbeing and to embed compassionate cultures at every level within institution for both students and staff.

\section{Data availability statement}

The data that support the findings of this study are not available due to ethical restrictions.

Acknowledgements

The authors would like to thank the students and staff who participates in this research.

\section{Disclosure statement}

No potential conflict of interest.

\section{References}

Atkins, P. W. B., \& Parker, S. K. (2012). Understanding individual compassion in organizations: The role of appraisals and psychological flexibility. Academy of Management Review, 37, 524-546. https://doi.org/10.5465/amr.2010.0490

Audin, K., Davy, J., \& Barkham, M., (2003). University Quality of Life and Learning (UNIQoLL): An approach to student wellbeing, satisfaction and institutional change. Journal of Further and Higher Education, 27(4), 365-382. https://doi.org/10.1080/0309877032000128073

Baik, C., Larcombe, W., \& Brooker, A., (2019). How universities can enhance student mental wellbeing: the student perspective. Higher Education Research and Development, 38(7), 1-14. 
https://doi.org/10.1080/07294360.2019.1576596

Baik, C., Larcombe, W., Brooker, A., Wyn, J., Allen, L., Brett, M., Field, R., \& James, R. (2016). A Framework for Promoting Student Mental Wellbeing in Universities. Melbourne.

Ball, S. (2003). The teacher's soul and the terrors of performativity. Journal of Education Policy, 18(2), 215-228. https://doi.org/10.1080/0268093022000043065

Barden, N., \& Caleb, R. (2019) Student Mental Health and Wellbeing in Higher Education: a practical guide. Sage eds.

Barnett, R. (2012). Learning for an unknown future. Higher Education Research \& Development, 31(1), 65-77. https://doi.org/10.1080/07294360.2012.642841

Bartunek, J. M., \& Rynes, S. L. (2010). The construction and contributions of "implications for practice": What's in them and what might they offer?. Academy of Management Learning \& Education, 9, 100-117. https://doi.org/10.5465/amle.9.1.zqr100

Bernstein-Yamashiro, B., \& Noam, G. G. (2013). Special Issue: Teacher-student relationships: Toward personalized education. New Directions for Youth Development, p. 137.

Biggs, J., \& Tang, C. (2011). Teaching for quality learning at university. 4th ed. Buckingham: The Society for Research into Higher Education \& Open University Press.

Braun, V., \& Clarke, V. (2006). Using Thematic Analysis In Psychology. Qualitative Research In Psychology, 3, 77-101. https://doi.org/10.1191/1478088706qp063oa

British Active Students Survey. (2018). 2017/2018 Report. UK Active, BUCS, Scottish Student Sport, and Precor. Retrieved from https://www.precor.com/sites/default/files/BASS\%20report\%20FINALA.PDF

Bücker, S., Nuraydin, S., Simonsmeier, B. A., Schneider, M., \& Luhmann, M. (2018) Subjective wellbeing and academic achievement: A meta-analysis. Journal of Research in Personality, 74, 83-94. https://doi.org/10.1016/j.jrp.2018.02.007

Clegg, S., \& Rowland S., (2010). Kindness in pedagogical practice and academic life. British Journal of Sociology of Education, 31(6), 719-735. https://doi.org/10.1080/01425692.2010.515102

Conley, C. S., Durlak, J. A., \& Kirsch, A. C. (2015). A meta-analysis of universal mental health prevention programs for higher education students. Prevention Science, 16(4), 487-507. https://doi.org/10.1007/s11121-015-0543-1

Deasy, C., Coughlan, B., Pironom, J., Jourdan, D., \& Mannix-Mcnamara, P. M. (2014). Psychological distress and lifestyle of students: implications for health promotion. Health promotion international, 30(1), 77-87. https://doi.org/10.1093/heapro/dau086

Deci, E. L., \& Ryan, R. M. (2008). Hedonia, eudaimonia, and wellbeing: An introduction. Journal of happiness studies, 9(1), 1-11. https://doi.org/10.1007/s10902-006-9018-1

Denovan, A., \& Macaskill, A. (2017). Stress and subjective well-being among first year UK undergraduate students. Journal of Happiness Studies, 18(2), 505-525. https://doi.org/10.1007/s10902-016-9736-y

Denzine, G. M., \& Pulos, S. (2000). College students' perceptions of faculty approachability. Educational Research Quarterly, 24, 56-66.

Dollinger, M., Lodge, J., \& Coates, H. (2018). Co-creation in higher education: towards a conceptual model. Journal of Marketing for Higher Education, 28(2), 210-231. https://doi.org/10.1080/08841241.2018.1466756

Dooris, M., \& Doherty, S. (2010). Healthy Universities: current activity and future directions-findings and reflections from a national-level qualitative research study. Global health promotion, 17(3), 1-16. https://doi.org/10.1177/1757975910375165

El Ansari, W., \& Stock, C. (2010). Is the health and wellbeing of university students associated with their academic performance? Cross sectional findings from the United Kingdom. International journal of environmental research and public health, 7(2), 509-527. https://doi.org/10.3390/ijerph7020509

Fitzmaurice, M. (2008). Voices from within: Teaching in higher education as a moral practice. Teaching in Higher Education, 13, 341-352. https://doi.org/10.1080/13562510802045386

Geertshuis, S. A. (2019) Slaves to our emotions: Examining the predictive relationship between emotional 
wellbeing and academic outcomes. Active Learning in Higher Education, 20(2), 153-166. https://doi.org/10.1177/1469787418808932

Gil, N. (2015). Majority of students experience mental health issues, says NUS survey. The Guardian.

Goodhart, F. W., Hsu, J., Baek, J. H., Coleman, A. L., Maresca, F. M., \& Miller, M. B. (2006). A view through a different lens: Photovoice as a tool for student advocacy. Journal of American College Health, 55(1), 53-56. https://doi.org/10.3200/JACH.55.1.53-56

Graham, A., Powell, M. A., \& Truscott, J. (2016). Facilitating student well-being: relationships do matter, Educational Research, 58(4), 366-383. https://doi.org/10.1080/00131881.2016.1228841

Graham, C. (2010). Hearing the voices of general staff: A Delphi study of the contributions of general staff to student outcomes. Journal of Higher Education Policy and Management, 32(3), 213-223. https://doi.org/10.1080/13600801003743315

Gulliver, A., Farrer, L., Bennett, K., \& Griffiths, K. M. (2019). University staff mental health literacy, stigma and their experience of students with mental health problems. Journal of Further and Higher Education, 43(3), 434-442. https://doi.org/10.1080/0309877X.2017.1367370

Hagenauer, G., \& Volet, S. E. (2014) Teacher-student relationship at university: an important yet under-researched field. Oxford Review of Education, 40(3), 370-388. https://doi.org/10.1080/03054985.2014.921613

Hammond, C. (2004). Impacts of lifelong learning upon emotional resilience, psychological and mental health: Fieldwork evidence. Oxford Review of Education, 30(4), 551-568. https://doi.org/10.1080/0305498042000303008

Harward, D. W. (2016). Wellbeing and Higher Education: A Strategy for Change and the Realization of Education's Greater Purposes. Washington, DC: Bringing Theory to Practice.

Harward, D. W. (2007). Engaged Learning and the Bringing Theory into Practice. Liberal Education, Winter, p. 6-15.

Heron, E. (2019). Friendship as method: reflections on a new approach to understanding student experiences in higher education. Journal of Further and Higher Education, 44(3), 1-15. https://doi.org/10.1080/0309877X.2018.1541977

Holland, L. (2018). Physical activity holds the key to improving student mental health. FE News.

Hone, L. C., Jarden, A., Schofield, G. M., \& Duncan, S. (2014). Measuring flourishing: The impact of operational definitions on the prevalence of high levels of wellbeing. International Journal of Wellbeing, 4, 62-90. https://doi.org/10.5502/ijw.v4i1.4

Houghton, A., \& Anderson, J. (2017). Embedding mental wellbeing in the curriculum: maximising success in higher education. York, UK: Higher Education Academy.

House of Commons Library. (2019). Support for students with mental health issues in higher education in England. London: UK Commons Library, p. 1-16.

Hughes, G., Panjwani, M., Tulcidas, P., \& Byrom, N. (2018). Student Mental Health: The Role and Experience of Academics. Student Minds.

Hughes, G., \& Spanner, L. (2019). The University Mental Health Charter. Leeds: Student Minds. https://doi.org/10.1037/t74201-000

Jacklin, A., \& Le Riche, P. (2009). Reconceptualising student support: From 'support' to 'supportive'. Studies in Higher Education, 34, 735-749. https://doi.org/10.1080/03075070802666807

Jordan, J. V., \& Schwartz, H. L. (2018). Radical Empathy in Teaching. New Directions For Teaching and Learning, 153(2), 25-35. https://doi.org/10.1002/t1.20278

Kahn, W. (2005). Holding Fast: The Struggle to Create Resilient Caregiving Organizations. Hove, UK: Brunner-Routledge. https://doi.org/10.4324/9780203324066

Keeling, R. P. (2014). An ethic of care in higher education: Wellbeing and learning. Journal of College and Character, 15(3), 141-148. https://doi.org/10.1515/jcc-2014-0018

Kadison, R., \& DiGeronimo, T. F. (2004). College of the overwhelmed: The campus mental health crisis and what to do about it. San Francisco, CA, US: Jossey-Bass. 
Komarraju, M., Musulkin, S., \& Bhattacharya, G. (2010). Role of student-faculty interactions in developing college students' academic self-concept, motivation, and achievement. Journal of College Student Development, 51, 332-342. https://doi.org/10.1353/csd.0.0137

Kruisselbrink, F. A. (2013). A Suffering Generation: Six Factors Contributing to the Mental Health Crisis, North American Higher Education. College Quarterly, 16(1), n1.

Levecque, K., Anseel, F., De Beuckelaer, A., Van der Heyden, J., \& Gisle, L. (2017). Work organization and mental health problems in PhD students. Research Policy, 46(4), 868-879. https://doi.org/10.1016/j.respol.2017.02.008

Lilius, J. M., Worline, M. C., Maitlis S., Kanov, J., Dutton, J. E., \& Frost, P. (2008). The contours and consequences of compassion at work., J. Organiz. Behav., 29, 193-218. https://doi.org/10.1002/job.508

Lilius, J. M., Worline, M. C., Dutton J. E., Kanov, J., \& Maitlis, S. (2011). Understanding Compassion Capability. Human Relations, 64(7), 873-899. https://doi.org/10.1177/0018726710396250

Maben, J. (2013). Focus on staff wellbeing: National Nursing Research Unit director Jill Maben reveals how research findings show a strong connection between staff happiness and patient satisfaction. Nursing Standard, 27(34). https://doi.org/10.7748/ns2013.04.27.34.61.s52

Maben, J., Peccei, R., Adams, M., Robert, G., Richardson, A., Murells, T., \& Morrow, E. (2012). Exploring the Relationship between Patients' Experiences of Care and the Influence of Staff Motivation, Affect and Wellbeing. National Institute for Health Research.

Macaskill, A. (2012). The Mental Health of University Students in the United Kingdom. British Journal of Guidance and Counselling, 41(4), 426-441. https://doi.org/10.1080/03069885.2012.743110

Madden, L. T., Duchon, D., Madden, T. M., \& Plowman, D. A. (2012). Emergent organizational capacity for compassion. Academy of Management Review, 37, 689-708. https://doi.org/10.5465/amr.2010.0424

Marshall, S. (2019). A Handbook for Teaching and Learning in Higher Education. Routledge. https://doi.org/10.4324/9780429259500

Meehan, C., \& Howells, K. (2019). In search of the feeling of 'belonging' in higher education: undergraduate students transition into higher education. Journal of Further and Higher Education, 43(10), 1376-1390. https://doi.org/10.1080/0309877X.2018.1490702

Mikalajūnaitè, U. (2019). Rising Mental Health Crisis In China's Universities. EdSurge Independent.

Mascaskill, A. (2012). University student mental health in crisis: A United Kingdom perspective. Br. J. Guid. Counsel, 41, 426-41. https://doi.org/10.1080/03069885.2012.743110

McCulloch, A. (2009). The student as co-producer: learning from public administration about the student-university relationship. Studies in Higher Education, 34(2), 171-183. https://doi.org/10.1080/03075070802562857

McIntosh, E., \& Shaw, J. (2017). Student Resilience. Exploring the positive case for resilience. Unite Students.

Morgan, H., \& Houghton, A. (2011). Inclusive curriculum design in higher education. Considerations for effective practice across and within subject areas. York, UK: Higher Education Academy.

Morrish, L. (2019). Pressure Vessels: The epidemic of poor mental health among higher education staff, (HEPI Occasional Paper 20). Higher Education Policy Institute.

Neves, J., \& Hillman, N. (2018). Student Academic Experience Survey. AdvanceHE and Higher Education Policy Institute.

Nowell, L., Norris, J., White, D., \& Moules, N. (2017). Thematic Analysis: Striving to Meet the Trustworthiness Criteria. International Journal of Qualitative Methods, 16, 1. https://doi.org/10.1177/1609406917733847

O'Brien T., \& Guiney, D. (2018). Staff Wellbeing in Higher Education. A research study for Education Support Partnership. London, UK: Education Support Partnership.

Okanagan Charter: An International Charter for Health Promoting Universities and Colleges. (2015).

O'Keeffe, P. (2013). A sense of belonging: Improving student retention. College Student Journal, 47(4), 605-613.

Pascarella, E. T., \& Terenzini, P. T. (2005). How college affects students: A third decade of research (2nd ed.). San Francisco: Jossey-Bass.

Pidgeon, A. M., Rowe, N. F., Stapleton, P., Magyar, H. B., \& Lo, B. C. (2014). Examining characteristics of 
resilience among University students: An international study. Open journal of social sciences, $2(11), 14$. https://doi.org/10.4236/jss.2014.211003

Postareff, L., \& Lindblom-Ylänne, S. (2011). Emotions and confidence within teaching in higher education. Studies in Higher Education, 36, 799-813. https://doi.org/10.1080/03075079.2010.483279

Roffey, S. (2012). Pupil wellbeing -Teacher wellbeing: Two sides of the same coin?. Educational and Child Psychology, 29, 8-17.

Roorda, D. L., Koomen, H. M. Y., Spilt, J. L., \& Oort, F. J. (2011). The influence of affective teacher-student relationships on students' school engagement and achievement: A meta-analytic approach. Review of Educational Research, 81, 493-529. https://doi.org/10.3102/0034654311421793

Royal College of Psychiatrists. (2011). Mental health of students in higher education. Retrieved from https://www.rcpsych.ac.uk/docs/default-source/improving-care/better-mh-policy/college-reports/college-rep ort-cr166.pdf?sfvrsn=d5fa2c24_4

Ryan, R. M., \& Deci, E. L. (2001). On happiness and human potentials: A review of research on hedonic and eudaimonic wellbeing. Annual review of psychology, 52(1), 141-166. https://doi.org/10.1146/annurev.psych.52.1.141

Ryan, A., \& Tilbury, D. (2013). Flexible Pedagogies: new pedagogical ideas. York, UK: Higher Education Academy.

Ryan, R. M., \& Deci, E. L. (2017). Self-Determination Theory: Basic Psychological Needs in Motivation, Development, and Wellness. Guilford Press 2017. https://doi.org/10.1521/978.14625/28806

Rynes, S. L., Bartunek, J. M., Dutton, J. E., \& Margolis, J. D. (2012). Care and compassion through an organizational lens: Opening up new possibilities. The Academy of Management Review, 37(4), 503-523. https://doi.org/10.5465/amr.2012.0124

Sabri, D., (2011). What's wrong with 'the student experience'?. Discourse: Studies in the Cultural Politics of Education, 32(5), 657-667. https://doi.org/10.1080/01596306.2011.620750

Schmidt, M., \& Hansson, E., (2018). Doctoral students' wellbeing: a literature review. International Journal of Qualitative Studies on Health and Well-being, 13(1), 1508171. https://doi.org/10.1080/17482631.2018.1508171

Seldon, A., \& Martin, A. (2017). The Positive and Mindful University (HEPI Occasional Paper 18). Higher Education Policy Institute.

Smyth, J. (2017). The toxic university: Zombie leadership, academic rock stars, and neoliberal ideology. London: Palgrave Macmillan. https://doi.org/10.1057/978-1-137-54968-6

Stanton, A., Zandvliet, D., Dhaliwal, R., \& Black, T. (2016). Understanding students' experiences of wellbeing in learning environments. Higher Education Studies, 6(3), 90-99. https://doi.org/10.5539/hes.v6n3p90

Stephen, D. E., O’Connell, P., \& Hall, M. (2008). 'Going the extra mile', 'fire-fighting', or laissez-faire? Re-evaluating personal tutoring relationships within mass higher education. Teaching in Higher Education, 13, 449-460. https://doi.org/10.1080/13562510802169749

Swaner, L. E. (2007). Linking Engaged Learning, and Wellbeing, and Civic. A Review of the Literature Liberal Education. Winter. p. 16-25.

Thompson, V. A. (2007). Without Sympathy or Enthusiasm: The Problem of Administrative Compassion. University of Alabama Press.

Thorley, C. (2017). Not by Degrees: Improving Student Mental Health in the UK's Universities. London: Institute for Public Policy Research.

Trigwell, K. (2012). Relations between teachers' emotions in teaching and their approaches to teaching in higher education. Instructional Science, 40, 607-621. https://doi.org/10.1007/s11251-011-9192-3

Turner, M., Holdsworth, S., \& Scott-Young, C. M. (2017). Resilience at university: The development and testing of a new measure. Higher education research \& development, 36(2), 386-400. https://doi.org/10.1080/07294360.2016.1185398

UBC Wellbeing. (2016). Teaching practices that promote student wellbeing: a tool for educators. The University of British Columbia. 
Universities UK. (2015). Student mental well-being in higher education. London: Universities UK.

Universities UK. (2018). Suicide -Safer Universities. London: Universities UK.

Universities UK. (2019) Whole University Approach. London: Universities UK.

Van Petegem, K., Aelterman, A., Van Keer, H., \& Rosseel, Y. (2008). The influence of student characteristics and interpersonal teacher behaviour in the classroom student's wellbeing. Soc Indic Res, 85, 279-291. https://doi.org/10.1007/s11205-007-9093-7

Waddington, K. (2016). The compassion gap in UK universities. International Practice Development Journal, 6(1). https://doi.org/10.19043/ipdj.61.010

Waddington, K. (2017). Creating conditions for compassion. In P. Gibbs (Ed.), The Pedagogy of Compassion at the Heart of Higher Education. Cham: Springer. https://doi.org/10.1007/978-3-319-57783-8_4

Waddington, K. (2018). Developing Compassionate Academic Leadership: The Practice of Kindness, Journal of Perspectives in Applied Academic Practice, 6(3), 87-89. https://doi.org/10.14297/jpaap.v6i3.375

Wonkhe, (2019). Only the lonely - loneliness, student activities and mental wellbeing.

Wyn, J., Cahill, H., Holdsworth, R., Rowling, L., \& Carson, S. (2000). MindMatters, a whole-school approach promoting mental health and wellbeing. Australian \& New Zealand Journal of Psychiatry, 34(4), 594-601. https://doi.org/10.1080/j.1440-1614.2000.00748.x

Young, M. (2006). Stressed Out and Struggling: Higher Education Institutions and International Students' Mental Health.

\section{Copyrights}

Copyright for this article is retained by the author(s), with first publication rights granted to the journal.

This is an open-access article distributed under the terms and conditions of the Creative Commons Attribution license (http://creativecommons.org/licenses/by/4.0/). 